Portland State University

PDXScholar

1990

\title{
Study of referential and display questions and their responses in adult ESL reading classes
}

Susan Lindenmeyer

Portland State University

Follow this and additional works at: https://pdxscholar.library.pdx.edu/open_access_etds

Part of the Applied Linguistics Commons, and the Bilingual, Multilingual, and Multicultural Education Commons

Let us know how access to this document benefits you.

\section{Recommended Citation}

Lindenmeyer, Susan, "Study of referential and display questions and their responses in adult ESL reading classes" (1990). Dissertations and Theses. Paper 4070.

https://doi.org/10.15760/etd.5954

This Thesis is brought to you for free and open access. It has been accepted for inclusion in Dissertations and Theses by an authorized administrator of PDXScholar. Please contact us if we can make this document more accessible: pdxscholar@pdx.edu. 
AN ABSTRACT OF THE THESIS OF Susan Lindenmeyer for the Master of Arts in TESOL presented June 28, 1990.

Title: Study of Referential and Display Questions and their Responses in Adult ESL Reading Classes

APPROVED BY THE MEMBERS OF THE THESIS COMMITTEE:

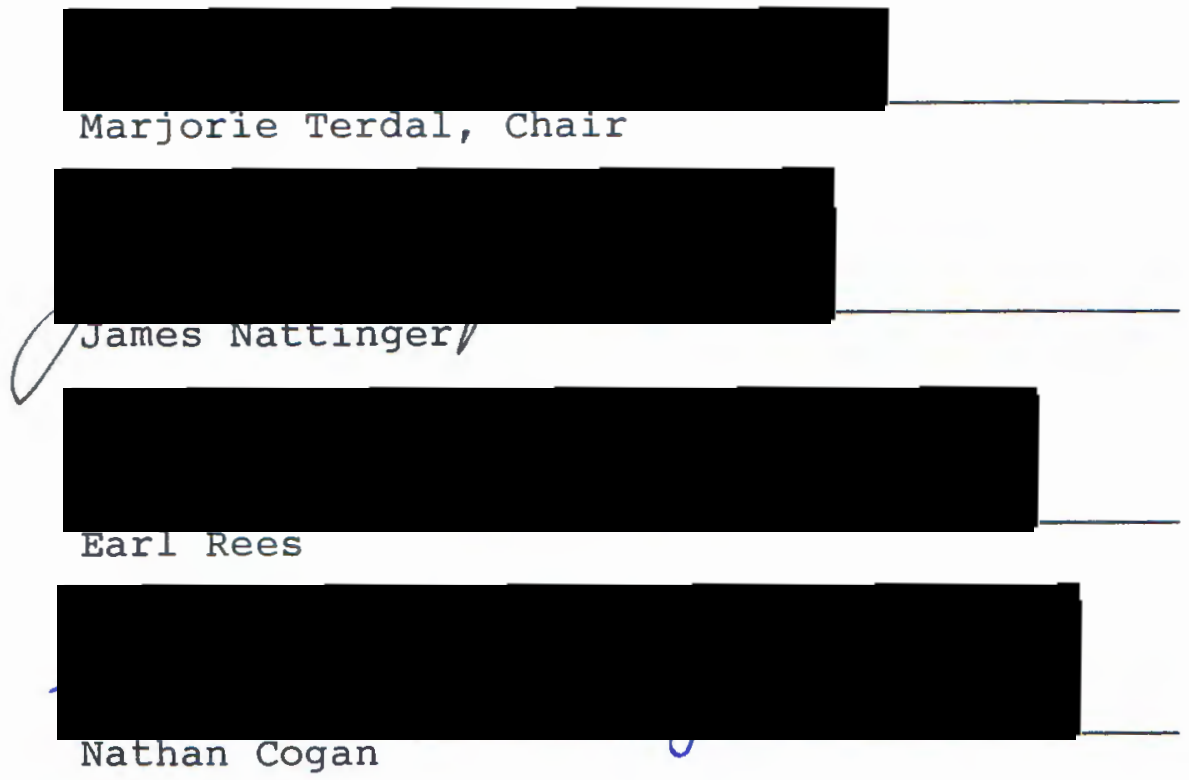

The technique of asking questions in the classroom has prevailed in first language classes for many years. This teaching technique has also been widely used in ESL reading classes. Though there has been extensive research about 
teachers' questions and students' responses in first language classrooms, there is a paucity of studies in second language classrooms.

This is a descriptive study of six experienced college level English as a Second Language (ESL) teachers and their discussions of the same reading selection with ninety-eight non-native speakers in each of their classes. Teacher-led discussions were audiotaped and twenty minutes of each class were transcribed and analyzed. Teachers' questions were coded according to Long and Sato's (1983) seven-category taxonomy of functions of teachers' questions. students' responses were analyzed according to their mean length, syntactic complexity, and the use of connectives.

The hypotheses posed were:

1. Reading teachers in adult ESL reading classes will ask a greater number of display than referential questions during teacher-student discussions.

2. Non-native speakers' responses to display questions will be shorter than their responses to referential questions.

3. Non-native speakers' responses to display questions will be syntactically less complex than their responses to referential questions.

4. Confirmation checks by the teacher will occur more frequently following referential questions than following display questions. 
5. Clarification requests by the teacher will occur more frequently following referential questions than following display questions.

6. Non-native speakers will use more connectives such as "and", "but", "because", and "so" in responses to referential questions than in responses to display questions.

A frequency count of referential and display questions confirmed the first hypothesis. Also students' responses to referential questions were found to be longer and more syntactically complex, and contained a greater number of connectives than in their responses to display questions. The teachers did not ask significantly more confirmation checks following referential questions than display questions. There was not a large enough sample of clarification requests to perform a statistical analysis for hypothesis five. 
STUDY OF REFERENTIAL AND DISPLAY QUESTIONS AND THEIR RESPONSES IN ADULT ESL READING CLASSES

by

SUSAN LINDENMEYER

A thesis submitted in partial fulfillment of the requirements for the degree of

MASTER OF ARTS

in

TESOL 
TO THE OFFICE OF GRADUATE STUDIES:

The members of the committee approve the thesis of Susan Lindenmeyer presented June 28, 1990.

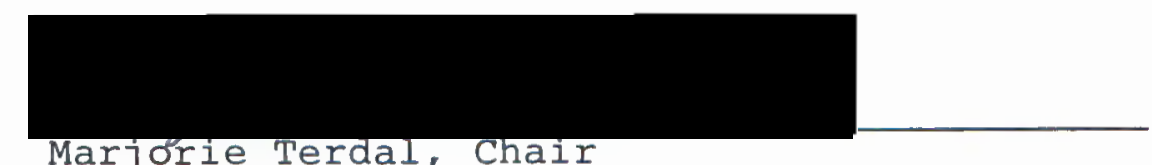

Marjorie Terdal, Chair
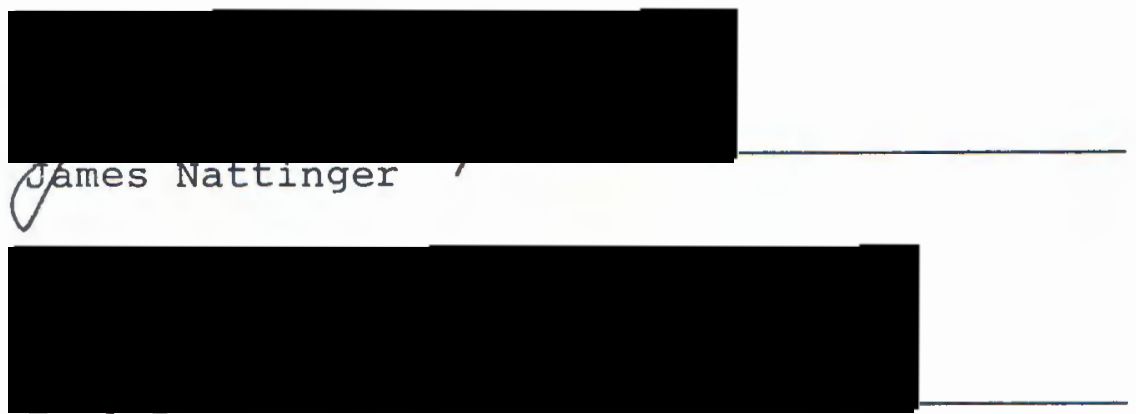

Ear 1 Rees

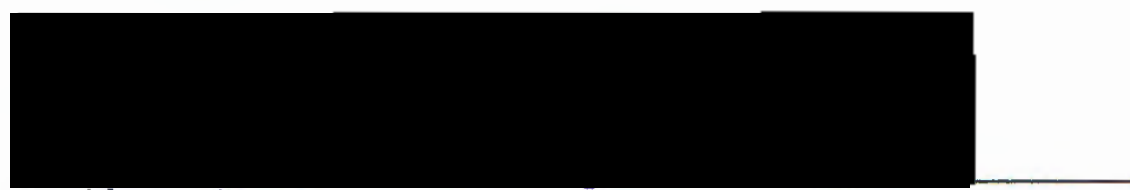

Nathan Cogan

APPROVED:

poames Nattinger/ chalr, Department of Applied Linguistics

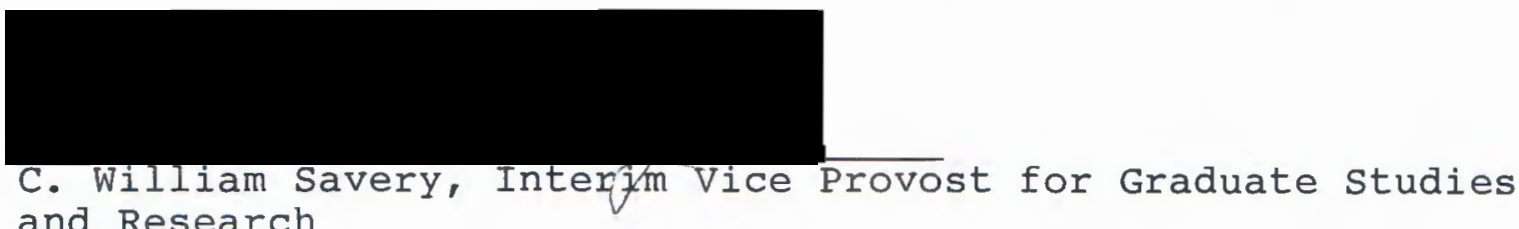
and Research 


\section{ACKNOWLEDGEMENTS}

Many people have contributed in a variety of ways to the completion of this study. I would like to offer my sincere gratitude to my advisor, Marjorie Terdal, for her patience and forthright advice. I would like to thank the members of my committee--James Nattinger, Earl Rees, and Nathan Cogan--for their time and valuable comments. Also a thank you to the six ESL teachers and ninety-eight students who permitted me to conduct this research in their classrooms.

My family and friends have been supportive of me throughout my graduate studies. I give my thanks to my patient and understanding husband, Patrick; to Sharon Hennessey for her input on this study as well as her help with childcare; and to Sharon Irwin for her words of encouragement and care of my child. A special thank you goes out to my friend and typist, who happens to be my mother-in-law, Ruth Sarvello, for her patience and diligence.

Finally, I would like to express thanks to my mother, Evelyn Farber, who has encouraged me in all my endeavors with her positive and strong outlook on life. 
TABLE OF CONTENTS

ACKNOWLEDGEMENTS.........................

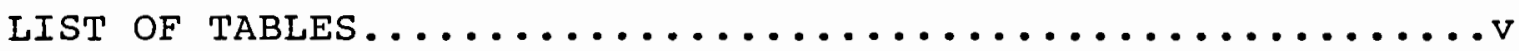

CHAPTER

I INTRODUCTION........................

Statement of Hypotheses..............

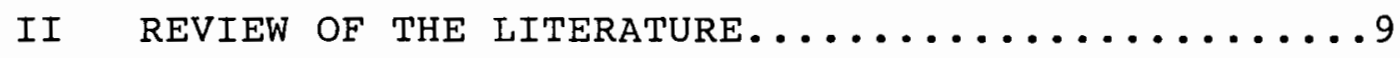

Questions in First Language Classrooms....11

Relevance of Questions in ESL..........19

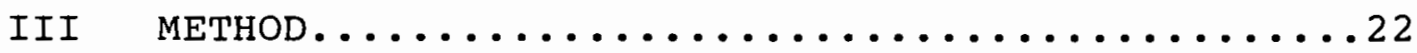

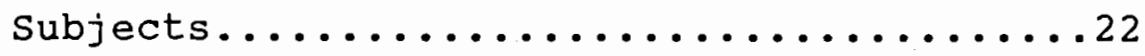

Procedures........................23

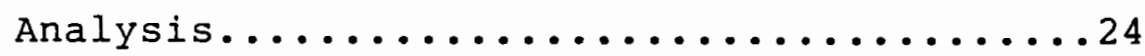

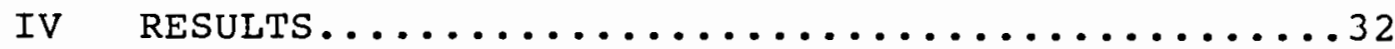

$\mathrm{V}$ SUMMARY AND DISCUSSION................ 41

Implications for Teaching ..........52

Limitations ........................

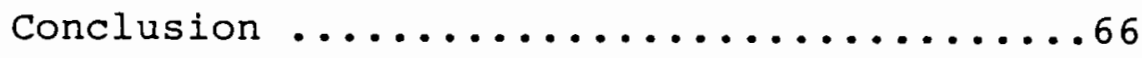

REFERENCES............................ 67 APPENDICES

A READING SELECTION AND VOCABULARY LIST........71

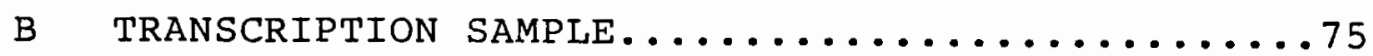




\section{LIST OF TABLES}

TABLE

PAGE

I Frequency of Referential and

Display Questions

II Mean Length (In Words) of Learner

Responses to Referential Questions

by Class

III Mean Length (In Words) of Learner

Responses to Display Questions

by Class

IV Total Mean Length (In Words) of Learner Responses in All Classes

$\mathrm{V}$ Mean Number of $\mathrm{S}$-Nodes Per $\mathrm{C}$-Unit in Learner Responses to

Referential Questions

VI Mean Number of S-Nodes Per C-Unit in Learner Responses to

Display Questions

VII Syntactic Complexity of Learner Responses (Mean Number of S-Nodes Per C-Unit) in All Classes

VIII Frequency of Confirmation Checks

IX Frequency of clarification Checks

$\mathrm{X}$ Connectives in Learner speech 
CHAPTER I

INTRODUCTION

The use of questioning, a dominant method of instruction in first language classrooms, has likewise prevailed as a teaching technique in ESL reading (Brock, 1985). Outside the classroom, questions have been widely used by native speakers (NSs) to initiate and maintain conversation with non-native speakers (NNSs). Long (1984) has found that in informal conversations between NSs and beginning-level NNSs, questions are the form most frequently used by NSs to initiate topics, and due to frequent shifts in topic, the dominant form used to address NNSs.

According to Long and Sato (1983), questions can offer the NNS more chances to speak and can also make greater quantities of linguistic input comprehensible. If, then, question-answer interactions are an important as well as a large part of the NNSs exposure to the second language, a description and analysis of these interactions can contribute to the understanding of second language acquisition.

The purpose of this study is to describe teachers' questions and students' responses in adult English as a 
Second Language (ESL) classrooms. By describing this process as it actually happens in the ESL classroom, a better understanding of student-teacher interaction will be reached. Long and Sato's (1983) seven-category taxonomy was used to code teachers' questions according to their functions. Students' responses were analyzed according to their length, syntactic complexity, and number of connectives.

Looking both outside and inside the second language classroom, questions are seen as an important tool for communication in the target language. However, it is surprising to find very little research on the functions of questions in ESL classroom discourse. Included in the few studies that looked at teacher-student question and answer interactions in the ESL classroom was a study by white and Lightbown (1984). This study analyzed the question and answer exchanges between teachers and students at the secondary level by counting the number of questions asked by teachers and calculating the teachers' wait-time (wait-time is the time elapsed between questions and answers). Another study by Long and sato (1983) analyzed the forms and functions of teachers' questions inside the classroom compared to teachers' speech with NNSs outside the classroom. And finally, in an experimental study by Brock (1985), the frequency of referential questions was increased 
over display questions asked by teachers in adult ESL reading classes. Referential questions ask for information that is unknown to the questioner whereas display questions ask for information that is already known to the questioner. Brock looked at the effects the increase of frequency of referential questions had on ESL classroom discourse.

The study by Brock prompted a further investigation of teachers' questions in adult ESL reading classes by the writer. The present study is a partial replication of Brock's work on questions and their effect on ESL discourse. The purpose of this study, however, was descriptive rather than experimental as in Brock's study. As there was a noted lack of descriptive studies in ESL reading classes, this study will supply needed information. By observing and then describing actual teaching in detail, it is possible to understand what teachers do in the classroom (seliger \& Long, 1983), and to suggest how teaching techniques can be improved to provide more effective teaching. This study will investigate the relationship between the types of questions teachers ask and students' responses. Since questions constrain what can appropriately be said in response (Stubbs, 1983; Keenan, Schieffelin, and Platt, 1978 ) "it may be the case that these two types of questions, display and referential, may shape the language of responses to them in different ways" (Brock, 1985, p. 3). 
STATEMENT OF HYPOTHESES

In order to describe the teacher-student question and answer interactions in ESL reading classes the following hypothesis was taken from first language classroom studies:

1. Reading teachers in adult ESL reading classes will ask a greater number of display than referential questions during teacher-student discussions.

The remaining hypotheses are a partial replication of Brock's M.A. thesis completed at University of Hawaii at Manoa in 1984

2. Non-native speakers' responses to display questions will be shorter than their responses to referential questions.

3. Non-native speakers' responses to display questions will be syntactically less complex than their responses to referential questions.

4. Confirmation checks by the teacher will occur more frequently following referential questions than following display questions.

5. Clarification requests by the teacher will occur more frequently following referential questions than following display questions.

6. Non-native speakers will use more connectives such as "and", "but", "because", and "so" in responses to referential questions than in responses to display questions. 
A frequency count of referential and display questions was performed to evaluate Hypothesis (1). Referential questions ask for answers that are not known to the questioner. These questions provide new information to the questioner, while display questions test students' knowledge. The questioner already knows the answer but is asking the question to see if the student can "display" the answer. First language classroom studies have supported the hypothesis that teachers ask more questions at low cognitive levels than at high cognitive levels. In this study, display questions were considered to be at low cognitive levels and referential questions were considered to be at high cognitive levels. (Chapter II will provide more information on cognitive levels.)

Hypotheses (2), (3), and (6) describe students' answers to questions. For Hypothesis (2), the mean length (in words) of learner responses to referential and display questions was calculated. Immediately following the teachers' questions words in the students' responses were counted then divided by the number of responses taken by the students.

The syntactic complexity of students' responses to referential and display questions (Hypothesis 3) was measured by the mean number of sentence-nodes (s-nodes) per communication unit (c-unit). S-nodes for learner responses 
to referential and display questions were counted then divided by the number of communication units for referential and display questions. A communication unit as defined by Loban (1966) is "a group of words that cannot be further divided without loss of their essential meaning" (p. 6). An s-node is signalled by tensed verbs, infinitives and gerunds. (S-nodes and c-units are defined more thoroughly in Chapter III.)

To test Hypothesis (6) the total number of connectives in learner responses to referential questions was compared to the total number of connectives in learner responses to display questions. An extensive list compiled by Celce-Murcia and Larsen-Freeman (1973) was consulted in order to define the class of connectives. When teachers ask display questions in the classroom, a unique type of discourse surfaces. In searching for an answer, teachers may "provide the propositional structure into which the answer fits" (Brock, 1985, p. 22). Connectives may be supplied by the teacher so the students can fill in the blanks with the correct answer. However, in answering referential questions, students may be required to provide connections between propositions. Since these "connections between propositions are typically expressed by natural connectives such as 'and', 'because', and 'so'", (Van Dijk, 1977, p. 5), it is hypothesized that NNSs will use more 
connectives in response to referential questions than in response to display questions.

Hypotheses (4) and (5) deal with questions from Long and Sato's (1983) taxonomy of questions that ask for confirmation or clarification of an utterance. To test Hypothesis (4) the total number of confirmation checks made by teachers in their turns immediately after learner responses to referential questions was compared to the total number of confirmation checks immediately after learner responses to display questions. Confirmation checks are used "either to elicit confirmation that their user had heard and/or understood the previous speaker's previous utterance correctly or to dispel that belief" (Long \& Sato, 1983, p. 275). The teacher may repeat completely or partially the student's utterance.

To test Hypothesis (5) the total number of clarification requests made by teachers in their turns immediately after learner responses to referential questions was compared to the total number of clarification requests immediately after learner responses to display questions. Clarification requests ask the speaker to supply new information or to restate previous information. "While clarification requests are frequently realized by questions, they are also encoded in statements like, 'I don't understand', and through imperatives like 'Try again'" (Long 
\& Sato, 1983, p. 276). Both confirmation checks and clarification requests are used to verify information. If teachers already know the answers to display questions, they would rarely have to use confirmation checks or clarification requests to check the content of students' responses. On the other hand, in answering a referential question, students may present the teacher with information that is new for the teacher. Confirmation checks or clarification checks may be needed to understand the students' responses.

In summary, this study will give a descriptive analysis of teachers' questions and students' responses in adult ESL reading classes. Focusing on display and referential questions and the kinds of responses they elicit will allow for recommendations specifically suited for the second language classroom. If the use of referential questions is found to increase the length, complexity, and use of connectives in NNSS' speech, that is if output is increased in general, teachers could enhance their classroom teaching skills by increasing the number of referential questions used in the classroom. 
CHAPTER II

REVIEW OF THE LITERATURE

Questions are a large part of non-native speakers' exposure to the target language. In research outside the classroom, questions have been found to play an important role in native speaker/non-native speaker conversations (NS/NNS). Research on "foreigner talk" holds that the higher frequency and varied functions of questions are among the most important and consistent modifications made from NS-NS norms (Long \& Sato, 1983).

In "foreigner talk discourse" (NS-NNS conversation in which the NS uses a modified register, foreigner talk, to address the NNS), questions are thought to facilitate and sustain participation by the NNS. For example, they can serve to signal speaking turns for the NNS, to make conversational topics salient and generally to "compel" the NNS to participate ... (Long \& Sato, 1983, p. 269).

Although questions have been considered an important part of learners' input outside of the ESL classroom, there has been little research on questions inside the classroom. A recent (January 1990) computer search revealed just three studies that dealt with teachers' questions and students' answers within the ESL classroom. One of these studies by White and Lightbown (1984) counted the number of questions 
asked in four ESL classes in a secondary school and recorded the amount of time the teacher allowed for students to answer (wait-time). It was found that teachers asked almost all the questions in the classrooms observed, and students were not given enough time to answer teachers' questions before the teachers repeated or directed the question to another student. One of the recommendations from this study called for teachers to ask questions without already having knowledge of the answer; that is, White and Lightbown concluded that classroom activities should require students to exchange genuine information with the teacher. Also as important as the kinds of questions teachers ask was the allowance of several seconds by the teachers for students to answer questions. A final recommendation of this study was to allow students several seconds to begin an answer to a question and several more to finish the answer.

Another study by Long and sato (1983) analyzed the classroom speech of six teachers with regard to the forms and functions of their questions. This information was compared to the speech of thirty-six NSs with NNSs in informal conversations outside the classroom. Within these two settings, Long and Sato found significant differences in the proportions of two types of questions. In the classroom, there were significantly more display questions, which tend to test students' knowledge or give information already 
known to the questioner, than referential questions, which request information not known to the questioner. On the other hand, NSs in the informal conversations asked a majority of referential questions and no display questions.

The third study that dealt with teachers' questions and students' responses was by Brock (1986). Four experienced ESL teachers and twenty-four NNSs at university level participated in this study. Two of the teachers received training to increase the frequency of referential questions in their reading classes; two did not. All four teachers taught the same reading and vocabulary lesson to one group of six NNSs. The teachers in the treatment group did increase the number of referential questions in their lessons. Students' responses in the treatment group were found to be significantly longer, more syntactically complex, and contained a greater number of connectives than the control group.

\section{QUESTIONS IN FIRST LANGUAGE CLASSROOMS}

Although there have not been many studies of questions and their function in the ESL classroom, there has been much written about questions in the first language classroom. These studies provide data that are relevant to three major points in this study: 
the intellectual level of teachers' questions; the relationship between student achievement and the use of questions at higher intellectual levels; and the relationship between the types of questions teachers ask and certain features of their students' responses (Brock, 1985, p. 4).

Most studies reviewed here utilized two classification systems to define the intellectual or cognitive levels of questions.

One of these systems, Bloom's (1956) Taxonomy of Educational Objectives: Cognitive Domain, assigns questions to one of six levels of a hierarchy. At the lowest level are questions calling for recall of factual information. At level two are questions calling for comprehension of facts and responding by explanation, interpretation, or extrapolation. At level three are questions that ask for application of the facts. At levels four and five are questions that ask for the analysis of relationships between elements and for generalizing or synthesizing, respectively. Finally, at the highest cognitive level, level six, questions call for evaluation or judgement.

The other classification system frequently used for classifying teachers' questions was developed by Gallagher and Aschner (1963). This system is based on the Guilford (1956) Structure of Intellect Model, and is designed to classify the thought processes manifested in teacher-student 
dialogue. At the lowest level of this four category hierarchy are "cognitive-memory" questions which call for the recognition and recall of factual information. At the middle levels are "convergent" and "evaluative" questions that allow the respondent "to generate independently his own data within a data-poor situation or to take a new direction or perspective on a given topic" (Aschner and Gallagher, 1963, p. 187). At the highest level are evaluative questions which call for expressions of judgement.

Regardless of the classification systems used, research in first language classrooms shows that teachers tend to ask questions at low cognitive levels, the level of factual recall or recognition. This is true both in elementary schools (Guszak, 1967; Willson, 1973) and in secondary schools (Davis \& Tinslig, 1967; Gallagher, 1965). Both Bloom's taxonomy and Gallagher and Aschner's system classify questions that ask for students' recall of factual information at a low cognitive level. The category of display questions in Long and Sato's (1983) taxonomy seems to fit into this classification.

In contrast, questions that require students to evaluate, judge, or offer new ideas are classified at a high cognitive level. The category of referential questions in Long and Sato's (1983) taxonomy seems to fit into this classification. 
In looking at the relationship between student achievement and the use of questions at higher intellectual levels, research is inconclusive. There is little research of possible correspondences between the level of teachers' questions and features of the students' response but the majority of research that has been done suggests that the cognitive level of the questions does have an effect on the students' response (Brock, 1985).

student responses have been analyzed to determine whether they are at the same level of intellectual hierarchy as the teacher's questions. Gallagher and Aschner (1963), in a descriptive study of junior high school interaction, found that an increase in the frequency of divergent questions by teachers was associated with an increase in the number of divergent responses by the students. Along the same lines, willson (1973) showed in an experimental study of elementary social studies class discussions that the teachers' level of interaction with their students (levels were based on Bloom's (1956) taxonomy) was reflected in the level of the students' responses. Willson (1973) held that in order to improve the level of cognitive processes in the classroom, it would be necessary to raise the cognitive level of teachers' questions and thus bring about an increase in the level of the students' cognitive processes. However, Mills, Rice, Berlinor and Rosseau (1980) found that 
there was only a $50 \%$ chance of a correspondence between the cognitive level of the question and the cognitive level of the response. Also using Bloom's (1956) taxonomy, Arnold, Atwood and Rogers (1974) found a strong relationship between the question level and the level of cognitive functioning of elementary school students.

Another area of research focuses on the relationship between the types of questions teachers ask and certain features of their students' responses. These studies did not use the same systems of analysis but general patterns could be observed. It appears that responses to lower cognitive level questions, those calling for recognition or recall of factual information, are shorter and less syntactically complex than responses to higher cognitive level questions calling for analysis, interpretation or expression of subjective knowledge.

For example, Smith (1978) conducted two separate studies that confirmed the hypothesis that the language used by children in answer to higher level questions would contain significantly longer average communication units than would the answers to comprehension questions asked at a lower cognitive level. (A communication unit consists of a grammatically independent clause and its modifiers.)

In the first study, responses by sixty elementary school students in second and fourth grade to higher 
cognitive level and lower cognitive level questions were compared. These grade levels were selected to compare two distinct stages of Piaget's hierarchy of cognitive development. Each child was interviewed and asked factual and interpretive questions about stories and pictures presented. The subjects of both groups responded in significantly longer communication units to the interpretive level questions (higher cognitive levels) which involve "analysis, reconstruction, or inference of relationship" (Smith, 1978, p. 898). Furthermore, although there was no difference in the length of all the subjects' answers to factual questions, the fourth graders' responses were longer than the second graders' responses to interpretive questions; this may have reflected the difference in their cognitive development.

In the second study by Smith, the oral responses of elementary and secondary students to two types of teachers' questions were analyzed. Twenty teachers who were participating in a graduate level teacher education project aimed at improving questioning techniques designed and asked these two types of questions: narrow and broad.

The narrow questions consisted of direct information questions requiring the students to develop a particular idea or answer by leading them toward it through clues .... The broad questions allowed for several acceptable answers. They included open-ended questions ... (Smith, 1978, p. 899). 
Tape recordings of the classroom questions and answers were collected from twenty teachers and then analyzed. Once again, the questions asked at the higher cognitive level (broad questions) elicited responses that were considerably longer than the answers to questions at the lower cognitive level (narrow questions).

Another descriptive study (Cole \& Williams, 1973) of eight teachers and their second to sixth graders looked at the relationship between teachers' questions and the cognitive level, length, and syntax of students' responses. The researchers wanted to operationalize some of the criteria put forth by Gall (1970) in order to measure whether any empirical relationship existed between the criteria and type of teacher questions. Gall's criteria included: complexity of the response; use of data to justify or defend the response; clarity of the phrasing; and the length and quality of the response.

Cole and Williams modified Gallagher and Aschner's (1963) classification of teachers' questions by categorizing students' responses and teachers' questions according to three levels: cognitive-memory, convergent thinking, and divergent and evaluative thinking. Students' responses were further categorized according to length and level of syntactic complexity. The results of this study indicate a significant association between the cognitive level of the 
teachers' questions and the cognitive level of students' responses and the length and syntax of those responses.

A study by Dillon (1981) does not conclusively support the findings from the studies described above by cole and Williams, and smith. In a descriptive study, Dillon classified teachers' questions in a number of ways. One of these classifications was a "fact" versus "opinion" dichotomy which is similar to the lower and upper levels of the other cognitive-level systems (Brock, 1985). He also classified questions with respect to their structure:

The syntactic structure of [a question] indicated the minimum amount of response adequate on grammatical grounds. A closed [question] was so structured that a single word or phrase was sufficient in response. An open [question] required at minimum several phrases or a sentence (Dillon, 1981, pp. 2-3).

Except in two instances, there was no significant difference in any of the ways Dillon classified teachers' questions. However, there was a difference between the fact and opinion questions in that students' responses to opinion questions were significantly longer than their responses to fact questions. Also there was a difference in the length of responses to open questions compared with closed questions. Contrary to expectations though, the mean length of response to closed questions was significantly longer than the mean length of student response to open questions. 
Brock (1985) attributes these results to Dillon's definition of student response as "the duration of student talk following upon one teacher utterance and terminating at the next" (Dillon, 1982, p. 2). In other words, if Dillon had examined students' responses in a different manner, he might have found that a given number of students would have produced short responses one after another in a series.

\section{RELEVANCE OF QUESTIONS IN ESL}

Most of the classification systems of questions in the studies described thus far utilize the same intellectual continuum but with different names and different definitions. The questions at the higher end of the continuum calling for evaluation, can be considered referential questions. Conversely, the questions at the lower end of the continuum, such as those calling for factual recall, can be considered display questions. However, "the explicit distinction between display and referential questions seems not to have figured prominently in first-language classroom research" (Brock, 1985, p. 17) even though using display questions in the classroom creates a unique type of discourse. Mehan (1979) observes that the use of known information questions, display questions, reflects the one-way flow of information from teachers to students found in most classrooms. Therefore, 
"conversations in classrooms have unique features, and ... the demands of classroom discourse must be kept separate from the demands of everyday discourse" (Mehan, 1979, p. 294).

Since everyday discourse is likely to be the target discourse for second language learners, the use of known information questions which generate discourse that is different from normal conversation should be taken into consideration by language teachers. That is, if referential questions create a flow of information from students to teachers which more closely resembles everyday discourse outside the classroom walls, then the use of referential questions by language teachers in the classroom can be recommended. Because "many writers on language-teaching methodology in the last twenty years have encouraged teachers to focus ... on communication" (Long, 1983) by using more referential questions in discussions, teachers would be emphasizing meaning over accuracy in communication. In conclusion, many first language studies have investigated the cognitive levels of teachers' questions and their relationship to students' responses. Utilizing studies that have been concerned with cognitive levels in the first language classroom, this study applies the general findings to the second language reading classroom. In carrying out this descriptive study, research that is 
relevant to student-teacher interactions in the second language classroom is presented. 
CHAPTER III

METHOD

SUBJECTS

The subjects for this study were six teachers and ninety-eight non-native students in ESL reading classes in local community colleges. The six teachers, five women and one man, were all trained in a TESOL program at a state university. Four of the six had Master's degrees: three in TESOL and one in History. Four had TESOL certification. Among the teachers, the amount of teaching experience ranged from one year to fourteen years with an average of seven and one half years of experience. The majority of the students were from the East Asian countries of China, Japan, Korea, Vietnam, Laos and Cambodia while others were from Mexico, Guatemala, Turkey, USSR, Poland, and Czechoslovakia. Sixty-eight of the students were enrolled in the highest level of a non-credit reading class for adult refugees and immigrants at one community college offered through the Adult Basic Education/General Equivalency Diploma/English as a Second Language (ABE/GED/ESL) Department. Twenty of the students were enrolled in the highest level of a 
credit-bearing reading class for non-native speakers (NNSs) that is offered through the English Department at the same community college. The remaining ten students were enrolled in a reading class for non-native speakers at another community college that combined levels where credit/no-credit was an option. All students were placed in their levels according to internal placement tests.

\section{PROCEDURES}

Teachers were given the reading passage, women in the Nuclear Family, and the list of vocabulary words (See Appendix A). No special instructions were given to the teachers except that there should be some kind of teacher-student interaction. The teachers were told that the purpose of the study was to examine some unnamed aspects of classroom language.

While the reading selections were discussed, each class was audiotaped and the researcher was present. The researcher took notes that helped to identify change of speakers, and observed verbal and non-verbal activities that may have had an effect on the research. Approximately one hour of each reading class was audiotaped. The first twenty minutes of the teacher directed portion of the reading lesson dealing with the supplied reading selection was transcribed for analysis. Small groups of student-led 
discussions were not used in the analysis. The tape recordings of the teachers' lessons of the reading selection were made between the second and fifth weeks of an eight week term.

ANALYSIS

Long and Sato's (1983) adaptation of Kearsley's (1976) taxonomy was used to code question types according to their functions. The seven categories of questions were the following:

A. Echoic: questions which ask for a confirmation or clarification of an utterance

1. Comprehension checks (e.g., All right?, Does everyone understand " "?)

2. Clarification requests (e.g., What?, Huh?, I don't understand.)

3. Confirmation checks (e.g., Did you say "he"?, Student: Carefully. Teacher: Carefully?)

B. Epistemic: questions which serve the purpose of acquiring knowledge

1. Referential--supply contextual information (e.g. Why did he do that?)

2. Display--"test" or "known information" (e.g. What is the opposite of "up"?)

3. Expressive--convey attitude to the addressee 
(e.g. Words are interesting, aren't they?)

4. Rhetorical--asked for an effect

No answer is expected from students (e.g.

Why do we do that? Because...)

All questions from the six teachers' classes were coded according to the seven-category taxonomy above. All the categories were used in testing the six hypotheses except for the last two: expressive and rhetorical questions. These two categories were included in the coding but not used in the analysis.

According to Kearsley, referential questions are "intended to provide contextual information about situations, events, actions, purposes, relationships, or properties" (Kearsley, 1976, p. 361). The answers to these questions are not known to the questioner. An example of this type of question from the corpus is: "What's the most important decision that was made in your family this month?" However, display questions that test students' knowledge are not asked to acquire information but to "establish the addressee's knowledge of the answer" (Kearsley, 1976, p. 361). An example from this study is: "What is a nuclear family?" (See Appendix B for a sample portion of the corpus.)

To test Hypothesis (1), the total number of referential questions asked by teachers was compared to the total number 
of display questions asked by teachers.

To test Hypothesis (2), the mean length of responses in words was calculated for students' responses to display and referential questions. For the purpose of this study, an utterance was considered a question if there was a rise in intonation. An utterance that compelled the student to respond in some manner was also considered a question. For example, if the teacher said "I don't understand," this was coded as a question because it compels the student to supply more information. A student's response was considered the turn immediately following the teacher's question. If the teacher or another student spoke again, the response was considered to have ended. An exception to this was when the teacher contributed a comment, but did not disrupt the student's communication unit (definition follows). If such a contribution occurred at the boundary of a communication unit (c-unit), the students' response was considered to have ended. Following is an example from the corpus:

1 T: And what did you say?

2 S: Three of the five members here would agree 3 the nuclear family...

4 T: Uh huh.

5 s: but I didn't.

6 T: Oh you didn't agree with it. Why did you disagree? 
In line 4 of the example above, the teacher's comment falls within the boundary of the student's c-unit. It does not disrupt or change the continuity of the student's message in line 5. Line 6, however, occurs at the end of the student's communication unit and marks the end of the student's response.

For the purpose of this study, pause fillers such as "uh" were not counted as words. However, minimal expressions of agreement such as "uh huh" and "hum" and clarification requests in the form of "huh?" were counted as words.

Repetitions of words were not counted, and contractions were counted as single words in the analysis. An example from the corpus: "I think think it's it's true of the woman in Europe..." "Think" and "it's" were counted only once respectively, and "it's" was counted as one word. If a student repeated an entire c-unit such as "Nuclear family. Nuclear family." that c-unit was only counted once.

semantically empty phrases such as "you know" and "well" when used at the onset of a speaking turn were also not included in the analysis.

Hypothesis (3) was tested by measuring the mean number of sentence-nodes (s-nodes) per communication unit (c-unit). Loban (1966) described a c-unit as a group of words that cannot be further divided without loss of their essential 
meaning.

For example, the sentence "I see a man with a woman" consists of one c-unit. The meaning of the sentence would be changed if it were divided into smaller grammatical units: "I see a man" "with a woman". However, a compound sentence such as "I see a man and I see a woman" consists of two c-units because it contains two independent grammatical structures: "I see a man" "and I see a woman". A sentence with a compound predicate, such as "I see a man and a woman", consists of one c-unit because it cannot be broken down into two meaningful grammatical structures. Loban (1966) explains the c-unit in further detail:

In all cases, the words comprising a communication unit are either independent grammatical predictions or answers to questions which lack only the repetition of the question elements to satisfy the criterion of independent prediction. Given this definition, the single word "yes" can be admitted as a whole unit of communication when it is an answer to a question $(1966$, p. 7).

As in Brock's study (1985), portions of non-native speech were qualified as a c-unit even if they lacked or included incorrectly the copula, the impersonal pronoun "it", an auxiliary verb, prepositions, articles or inflectional morphology.

Following Brock's study (1985), tensed verbs, infinitives, and gerunds were taken to signal an underlying s-node. Modals, such as "could" and "must" were not, 
however, considered to be a signal of underlying s-nodes. Further defining the s-node, Freed (1978) holds that a c-unit "may have several sentence nodes as a consequence of having several sentences, several clauses or being a run-on or compound sentence" (Freed, 1978, p. 43).

The following is an example from the corpus:

1 T: What happens to the mother?

2 S: If they have a daughter ... she works ... /

3 she get money .../ she take care of the 4 family.

The c-unit (marked by /) in line 2 has 2 s-nodes (underlined). Line 2 cannot be divided into a smaller unit without changing its essential meaning. Lines 3 and 4 , however, contain two c-units with one s-node in each.

The mean number of $s$-nodes per c-unit in learner responses to referential questions was compared with the mean number of $s$-nodes per c-unit in learner responses to display questions.

Using definitions in Long and Sato (1983) for confirmation checks and clarification requests, Hypotheses (4) and (5) were tested. Confirmation checks are either Yes/No or uninverted questions spoken with rising intonation that presuppose a "Yes" answer. 
They involve exact or semantic, complete or partial repetition of the previous speaker's questions and serve either to elicit confirmation that their user had heard and/or understood the previous speaker's previous utterance correctly or to dispel belief (Long \& Sato, 1983, p. 175).

On the other hand, clarification requests do not imply that the speaker has heard or understood the interlocutor's previous utterance. "They require that the interlocutor either furnish new information or recode the information previously given" (Long \& Sato, 1983, p. 276). Although clarification requests are usually in the form of a question, statements such as "I don't understand" or "Try again" can also function as requests for clarification and were therefore coded as questions in the analysis.

To test Hypothesis (4), the total number of confirmation checks made by the teachers in their turns immediately after learner responses to referential questions was compared to the total number of confirmation checks immediately after learner responses to display questions. Along the same lines, to test Hypothesis (5), the total number of clarification requests after learner responses to referential questions was compared to the total number of clarification requests immediately after learner responses to display questions.

To test Hypothesis (6), the total number of connectives in learner responses to referential questions was compared 
to the total number of connectives in learner responses to display questions. In order to define the class of connectives in this study, the extensive list compiled by Celce-Murcia and Larsen-Freeman (1973, p. 324-329) was consulted. Only connectives initiating a clause were counted. If speakers interrupted themselves or others interrupted, the connectives in those clauses were not counted.

To determine inter-rater reliability, a random sample from the corpus containing seventy-five questions was coded by another experienced ESI teacher. The sample was coded according to Long and Sato's (1983) taxonomy of the functions of questions. The seven categories of questions included: comprehension checks, clarification requests, confirmation checks, referential questions, display questions, expressive questions, and rhetorical questions. Agreement between the two coders for these seven categories was .86. Reliability ranged from .16 on rhetorical questions to 1.00 on expressive questions. Use of cell agreement for determining reliability is a conservative measure because it requires that each item be scored independently rather than simply considering group totals for each category. 
CHAPTER IV

\section{RESULTS}

In observing six ESL reading classrooms, twenty minutes of teacher-directed discussion about the reading, Women in the Nuclear Family, were audiotaped. Later the tapes were transcribed and analyzed according to Long and Sato's (1983) taxonomy of teachers' questions. Students' responses were analyzed according to their length, syntactic complexity, and use of connectives. The data were then statistically analyzed.

The Kruskal-Wallis one-way analysis of variance was used to analyze the frequency of referential and display questions asked by teachers. The Kruskal-Wallis test is a non-parametric statistical test that is analogous to the t-test. In this case the Kruskal-Wallis is more appropriate than the $t$-test because differences among more than two groups were measured. Table I shows the frequencies and total number of each of the two types of questions asked by the six teachers. Teachers asked significantly more display questions than referential questions in their classes (Kruskal-Wallis $\mathrm{H}=40.84, \mathrm{p}<.0001$ ), as predicted. The number of referential questions asked ranged from three 
questions asked by Teacher 3 , to twenty-eight questions asked by Teacher 6 . The number of display questions asked ranged from twelve questions asked by Teacher 5, to forty-four questions asked by Teacher 3. Of all referential and display questions asked, 38.738 were referential and $61.27 \%$ were display.

\section{TABLE I}

FREQUENCY OF REFERENTIAL AND DISPLAY QUESTIONS

Number of Referential

Questions Asked

$\begin{array}{lllllll}9 & 24 & 3 & 24 & 22 & 28 & 110\end{array}$

Number of Display

Questions Asked

2940

44

23

12

26

174

TOTAL Number of Referential and Display Questions Asked

$\begin{array}{llllllc}38 & 64 & 47 & 47 & 34 & 54 & 284 \\ \text { Kruskal-Wallis } & \mathrm{H}= & 40.84, & \mathrm{p}<0.0001\end{array}$

Table II shows the mean length (in words) of learner responses to referential questions by class. The range of the mean length (in words) of learner responses to referential questions was 2.6 words in Teacher 5's class in 8 responses to 13.6 words in Teacher 1 's class in 6 responses. Table III shows the mean length (in words) of learner responses to display questions by class. The range of the mean length (in words) of learner responses to 
display questions was smaller: 2.73 words in Teacher 4 's class in 19 responses to 7.62 words in Teacher 6's class in 16 responses. The number of responses to display questions was greater than or equal to the number of responses to referential questions in four of the six classes.

Table IV illustrates the mean length (in words) of learner responses to referential and display questions by all learners in all six classes. The mean length of all learner responses to referential questions was 8.30 words. The mean length of all learner responses to display questions was 3.76 words. There were approximately twice as many responses to display questions than to referential questions. As the standard deviation for learner responses to referential questions $(11.92)$ was greater than the standard deviation for learner responses to display questions (3.46), the t-test for separate variances was used. This is a more conservative measure than the t-test for pooled variances. A significant difference in the mean length (in words) of learner responses to referential and display questions was found $(t=3.22$, df $=72.88, p<.001)$. 


\section{TABLE II}

MEAN LENGTH (IN WORDS) OF LEARNER RESPONSES TO REFERENTIAL QUESTIONS BY CLASS

\begin{tabular}{|c|c|c|c|c|c|c|}
\hline & $\begin{array}{l}\mathrm{T} 1 \text { 's } \\
\text { Class }\end{array}$ & $\begin{array}{l}\text { T2's } \\
\text { Class }\end{array}$ & $\begin{array}{l}\text { T3's } \\
\text { Class }\end{array}$ & $\begin{array}{l}\text { T4's } \\
\text { Class }\end{array}$ & $\begin{array}{l}\text { T5's } \\
\text { Class }\end{array}$ & $\begin{array}{l}\text { T6's } \\
\text { Class }\end{array}$ \\
\hline Mean Length & 13.6 & 11.81 & 3.0 & 8.31 & 2.6 & 6.22 \\
\hline Number of Responses & 6 & 16 & 1 & 19 & 8 & 18 \\
\hline
\end{tabular}

\section{TABLE III}

MEAN LENGTH (IN WORDS) OF LEARNER RESPONSES TO DISPLAY QUESTIONS BY CLASS

\begin{tabular}{|c|c|c|c|c|c|c|}
\hline & $\begin{array}{l}\text { T1's } \\
\text { Class }\end{array}$ & $\begin{array}{l}\text { T2's } \\
\text { Class }\end{array}$ & $\begin{array}{l}\text { T3's } \\
\text { Class }\end{array}$ & $\begin{array}{l}\text { T4's } \\
\text { Class }\end{array}$ & $\begin{array}{l}\text { T5's } \\
\text { Class }\end{array}$ & $\begin{array}{l}\text { T6's } \\
\text { Class }\end{array}$ \\
\hline Mean Length & 3.25 & 2.97 & 3.57 & 2.73 & 4.5 & 7.62 \\
\hline Number of Responses & 16 & 37 & 40 & 19 & 4 & 16 \\
\hline
\end{tabular}

TABLE IV

TOTAL MEAN LENGTH (IN WORDS) OF LEARNER RESPONSES IN ALL CLASSES

\begin{tabular}{|c|c|c|c|}
\hline & Mean & $\begin{array}{l}\text { Number of } \\
\text { Responses }\end{array}$ & $\begin{array}{r}\text { Standard } \\
\text { Deviation }\end{array}$ \\
\hline $\begin{array}{l}\text { Learner Responses to } \\
\text { Referential Questions }\end{array}$ & 8.30 & 68 & 11.92 \\
\hline $\begin{array}{l}\text { Learner Responses to } \\
\text { Display Questions }\end{array}$ & 3.76 & 132 & 3.46 \\
\hline
\end{tabular}


Table $V$ shows the mean number of sentence nodes (s-nodes) per communication unit (c-unit) in learner responses to referential questions. In learner reponses to referential questions, the mean number of $s$-nodes per c-unit ranged from 0 in Teacher 3 's class to 1.37 in Teacher 1 's class. Table VI shows the mean number of $s$-nodes per c-unit in learner responses to display questions. In learner responses to display questions the mean number of $\mathbf{s}$-nodes per c-unit was lower than learner responses to referential questions: .4 in Teacher 5 's class to .72 in Teacher 6's class.

The syntactic complexity of all learner responses to both referential and display questions in the six classes is represented in Table VII. The mean number of $s$-nodes per c-unit in responses to referential questions was .88 , while the mean number of $s$-nodes per c-unit in responses to display questions was .41 . The t-test for separate variances was used to test for significance. As hypothesized, this difference was found to be significant $(t=4.11, \mathrm{df}=100, \mathrm{p}<.0001)$. 
TABLE V

MEAN NUMBER OF S-NODES PER C-UNIT IN LEARNER

RESPONSES TO REFERENTIAL QUESTIONS

$\begin{array}{lcccccr} & \text { T1's } & \text { T2's } & \text { T3's } & \text { T4's } & \text { T5's } & \text { T6's } \\ \text { Mean Number of } & \text { Class } & \text { Class } & \text { Class } & \text { Class } & \text { Class } & \text { Class } \\ \text { s-nodes per c-unit } & 1.37 & 1.21 & 0 & .93 & .11 & .63 \\ \text { Number of c-units } & 8 & 23 & 1 & 30 & 9 & 19\end{array}$

TABLE VI

MEAN NUMBER OF S-NODES PER C-UNIT IN LEARNER

RESPONSES TO DISPLAY QUESTIONS

\begin{tabular}{|c|c|c|c|}
\hline Class & $\begin{array}{l}\text { T2's } \\
\text { Class }\end{array}$ & $\begin{array}{l}\text { T3's } \\
\text { Class }\end{array}$ & $\begin{array}{l}\text { T4's } \\
\text { Class }\end{array}$ \\
\hline
\end{tabular}

Mean Number of

$\begin{array}{lllllll}\mathrm{s}-\text { nodes per c-unit } & .58 & .28 & .38 & .35 & .4 & .72\end{array}$

$\begin{array}{lllllll}\text { Number of c-units } & 12 & 38 & 39 & 17 & 5 & 18\end{array}$

TABLE VII

SYNTACTIC COMPLEXITY OF LEARNER RESPONSE

(MEAN NUMBER OF S-NODES PER C-UNIT)

IN ALL CLASSES

\begin{tabular}{|c|c|c|c|}
\hline & Mean & $\begin{array}{l}\text { Number of } \\
\text { C-units }\end{array}$ & $\begin{array}{r}\text { Standard } \\
\text { Deviation }\end{array}$ \\
\hline \multicolumn{4}{|l|}{ Learner Responses to } \\
\hline Referential Questions & .88 & 90 & .74 \\
\hline \multicolumn{4}{|l|}{ Learner Responses to } \\
\hline Display Questions & .41 & 129 & .54 \\
\hline
\end{tabular}


Table VIII shows the frequencies of confirmation checks by teachers immediately following learner responses to referential and display questions, as well as in other turns. For all six teachers there was a total of ten confirmation checks following learner responses to referential questions and seventeen confirmation checks following learner responses to display questions. This difference (Kruskal-Wallis $\mathrm{H}=11.11, \mathrm{p}<0.0490$ ) was found to be significant but in the opposite direction of that hypothesized.

TABLE VIII

FREQUENCY OF CONFIRMATION CHECKS

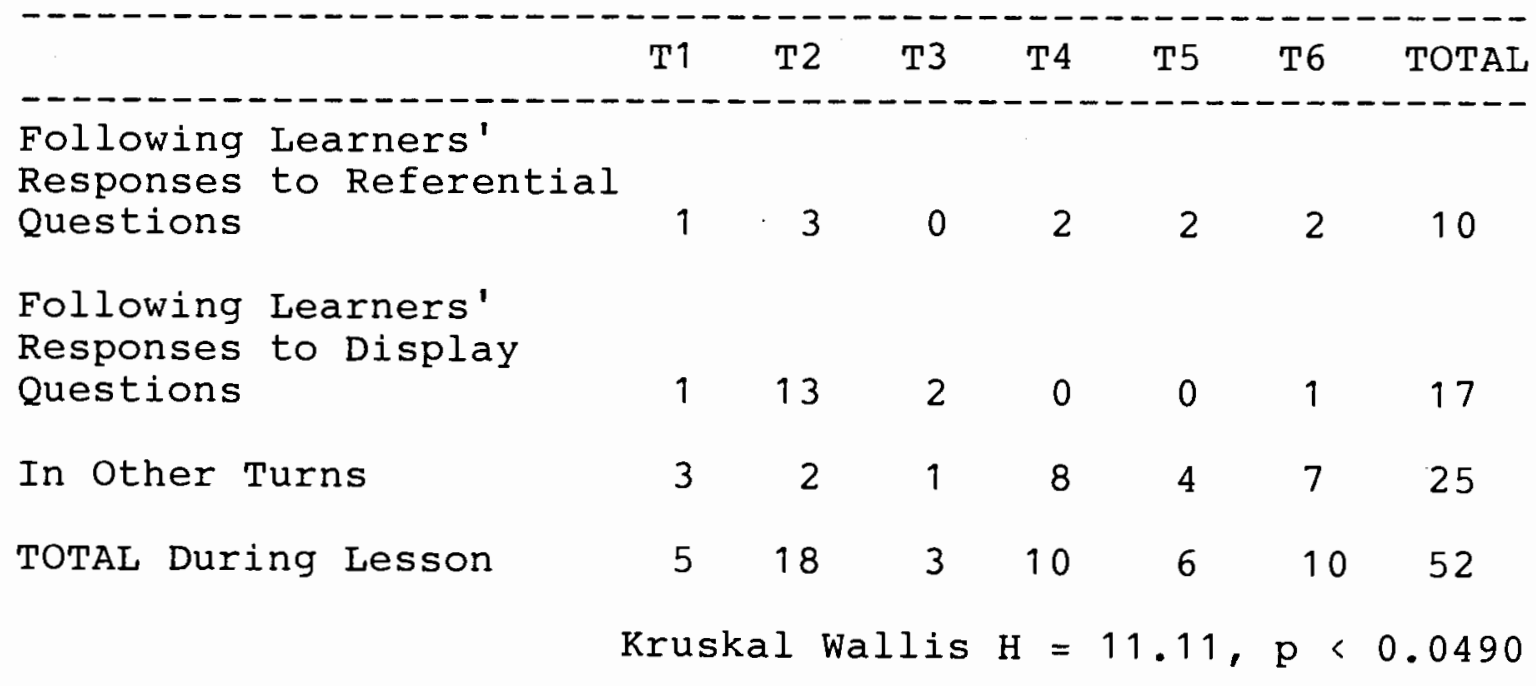


Table IX shows the frequencies of clarification requests by teachers immediately following learner responses to referential and display questions, as well as in other turns. There was too small a sample to perform a statistical analysis.

TABLE IX

FREQUENCY OF CLARIFICATION CHECKS

T1 T2 T3 T4 T5 T6 TOTAL

Following Learners'

Responses to Referential

Questions

0

10

$\begin{array}{lll}0 & 0 & 0\end{array}$

1

Following Learners'

Responses to Display

Questions

In Other Turns

TOTAL During Lesson

0

8

0

0

0

0

8

12

2

0

2

$0 \quad 1$

6

$1 \quad 1$

11

0

2

$0 \quad 1$

15

Table $\mathrm{X}$ presents the number of connectives used in each class. In response to referential questions all learners from the classes used a total of twenty-one connectives in their turns. In response to display questions, all learners from the classes used a total of five connectives in their turns. The most connectives during one class session (eight) were used during Teacher 2 's class in response to referential questions. 
TABLE X

CONNECTIVES IN LEARNER SPEECH

T1's T2's T3's T4's T5's T6's

Class Class Class Class Class Class TOTAL

In Response

To Referential

Questions

4

8

0

7

1

1

21

In Response

To Display

Questions

02

Kruskal Wallis $\mathrm{H}=15.92, \mathrm{p}<0.0070$

A significantly greater number of connectives were used in learner response to referential questions than display questions (Kruskal-Wallis $\mathrm{H}=15.92, \mathrm{p}(0.0070$ ).

In summary, four of the six hypotheses were supported by the statistical data. The results will be further discussed in Chapter $\mathrm{V}$. 


\section{CHAPTER V}

\section{SUMMARY AND DISCUSSION}

This study described teacher-student questions and answers in teacher-led discussions during adult ESL reading classes. Six experienced ESL teachers and their students (ninety-eight non-native speakers) discussed the same reading selection, Women in the Nuclear Family. The six classes were audiotaped and twenty minutes of each class were transcribed for analysis. Questions were coded according to a seven-category taxonomy developed by Long and sato (1983). Students' responses were analyzed according to their mean length, syntactic complexity, and the use of connectives.

of the six hypotheses posed, four were supported statistically. Teachers did not ask more confirmation checks following referential questions than display questions (Hypothesis 4). A statistical analysis could not be performed for Hypothesis (5) because the sample for the frequency of confirmation checks made by teachers was too small to analyze.

The first hypothesis, reading teachers in adult ESL reading classes will ask a greater number of display than 
referential questions during teacher-student discussions, was supported by the data. The six teachers as a whole asked a significantly greater number of display than referential questions. There was, however, individual variation. For example, Teachers 4 and 6 asked approximately an equal number of referential and display questions. Although the reading selection was the same for each of the six teachers, the teachers were free to approach the reading selection in any way, as long as there was student-teacher interaction.

All six teachers in some way, discussed the new vocabulary words found in the reading selection, women in the Nuclear Family. (The twenty-two word vocabulary list provided by the researcher with the reading selection is found in Appendix A). After pre-reading exercises and students' silent reading of the selection, Teachers 1 and 6 asked students which vocabulary words found in the selection were new to them. Before the students read, Teachers 2 and 5 utilized the vocabulary list supplied with the reading with the addition of one vocabulary word. Before the students of Teacher $3^{\prime}$ 's class and Teacher 4 's class began the reading, the teachers presented reduced vocabulary lists. All the teachers led the discussions that involved the vocabulary while the students in Teacher 5's class first defined the vocabulary in small groups then reviewed as a 
class with the teacher. The majority of vocabulary discussions was at a low cognitive level, reflected by the high frequency of display questions asked by the teachers. Looking at the teachers individually it is noted that approximately half of both Teacher $4^{\prime}$ s and 6's questions were referential questions. Although Teacher 4's lesson plan was similar to the other teachers', referential questions were used to draw out personal information from the students that had relevance to the lesson. Referential questions used by Teacher 6 also drew out personal thoughts and ideas when a pre-reading exercise of brainstorming with the word "family" was implemented.

In general, exercises that asked for students' opinions, personal background, and evaluations generated more referential questions from the teachers. Some of these exercises included brainstorming, small group student discussions, and teacher-led discussions. In turn, students' answers were longer, more syntactically complex and contained more connectives than their answers to display questions. It also should be noted that both Teacher 4 and Teacher 6 seemed to have established a level of trust within the classroom that may have fostered students' willingness to speak out.

Even though Teacher 5 asked twenty-two referential questions, which was almost double the number of display 
questions (twelve) asked, students responded only $36 \%$ of the time. This is the lowest percentage of students' responses to referential questions of all six teachers except for Teacher 3 , who asked only three referential questions during the lesson.

An example from the corpus will help to illustrate Teacher 5 's particular teaching style:

1 T: O.K. . In your family, who makes a lot of the 2 decisions, or made a lot of decisions when you were growing up? Was it your mother or your father? Who had more weight or pull or power when you were little? ... Maybe you wanted a bike or something ... did you ask your mother or father, or did you ask mom to ask your father or did you have a brother or sister who had a little bit more influence ... or could you persuade? How did the power work in your family? I'm curious. I know in my family sometimes I went to my 13 mother and she would persuade my father 14 depending on what it was and then ... 15 sometimes I went to my brother because he 16 was persuasive ...he could talk my dad into 17 anything .. So ... but usually it was my 18 father who had the final say. But, my 
mother had a lot of influence ... a lot of influence.

21 S: In Latin American countries we have something that we call machismo ...

The five questions (underlined) in lines 1 thru 11 were coded as referential questions. From the researcher's observation in the classroom and from listening to the audiotape, the fact that the teacher virtually did not allow time for students to respond, particularly to referential questions, can account for the different frequencies of referential and display questions. If Teacher 5 had not asked as many questions in succession and had increased the wait-time (duration of a pause between teacher and student talk), students might have had a greater chance to answer each question.

Hypothesis (2) stated that non-native speakers' responses to display questions will be shorter than their responses to referential questions. In fact, the length of students' responses to referential questions was on the average more than two times greater than students' responses to display questions. An example from Teacher 6's class follows:

1 T: O.K. What else do you think of when you 2 think of family? Does it give you a good feeling, or a bad feeling? Does it make you 
4

5

6

angry? Does it make you feel happy?

$S$ : Good feeling. Everyone is thinking of family ... Everyone laugh here probably.

The four questions in lines 1 thru 4 were coded as referential questions. The student's answer to the referential questions was eleven words long.

In answering display questions, students' responses were on the average, half as long as their responses to referential questions. An example follows:

1 T: If discontent means dissatisfied, what is a 2 word based on the same word that is positive? 3 S: content.

The question in lines 1 and 2 was coded as a display question. The student's answer to the display question was only one word long. The highest mean length of learner responses to referential questions was in Teacher 2 's class (13.6 words) where the majority of the referential questions asked students to give their opinion or evaluate. The lowest mean length ( 2.6 words) of learner responses to referential questions was found in Teacher 5 's class, although almost two times as many referential questions were asked as display questions.

Learner responses to referential questions were twice the syntactic complexity of learner responses to display questions. This supports the third hypothesis that states 
that non-native speakers' responses to display questions will be syntactically less complex than their responses to referential questions. Teacher 3's class had the lowest number of s-nodes per c-unit owing to the fact that only three referential questions in the whole discussion were asked. Teachers 5's class had the lowest number of $s$-nodes per c-unit (.11). The following is an example of one of the more complex learner responses to a referential question found in the corpus:

1 T: What about you, Tahh? Huh ...? The nuclear 2 family is better than others. What do you 3 think about that?

4 s: I think think it's it's true of the woman 5 in the Europe and and in this country/but 6 in Asia country the men don't don't like 7 this idea...

8 T: Ohhhhh..

9 s: $\quad \ldots$ because in the Asian the woman will 10 have more power/ and the women will have 11 freedom./ The men don't like.

There are four c-units (separated by /) and five s-nodes (underlined) in the above example. Connectives (discussed below) were underlined twice. The teacher's referential questions in the above example asked the student about his thoughts on the statement "The nuclear family is 
better than others." The student generated a syntactically more complex answer than the majority of answers to display questions.

The sixth hypothesis, non-native speakers will use more connectives such as "and", "but", "because", and "so" in responses to referential questions than in responses to display questions was supported. Learners did use more connectives to make links between propositions in repsonses to referential questions. (See example above.) The majority of connectives used were "and", "but" and "because". The most connectives used by learners (eight) during Teacher 2's class occurred when students were reporting their ideas following small group discussions of two opinion questions that would have been coded as referential questions if included in the corpus.

In order for NNSs to communicate successfully, the effective use of connectives is important. Connectives are considered global elements that when misused can lead to a communication breakdown. Tomiyana (1980) found in written communication that mistakes in the use of connectives linking clauses within sentences were more likely to cause breakdowns in communication than mistakes in the use of articles. It seems likely that connectives are important in oral communication and that using referential questions will increase the opportunity for their use. 
The fourth hypothesis holds that confirmation checks by the teacher will occur more frequently following referential questions than following display questions. This was not supported by the data. Furthermore, confirmation checks after learner responses to display questions were significantly more frequent than after learner responses to referential questions. In looking at the data, Teacher 2 asked the greatest number of confirmation checks following display questions (thirteen). The way in which Teacher 2 conducted the vocabulary discussion portion of the lesson most likely had an effect on this data. An example from the corpus follows:

1 T: So what's a group?

2 S: We are a group.

3 T: We are a group ... What is that? This is a 4 small group here. This is a big group. So 5 what is that?

6 S: A gathering.

7 T: A gathering?

8 S: Together.

9 T: Together?

To introduce the vocabulary, Teacher 2 led a class discussion asking the students for definitions of the words on the vocabulary list. In the example above, lines 7 and 9 were both classified as confirmation checks. However, 
these questions act more like teacher probes than true confirmation checks. These probes are pushing students to elaborate rather than checking meaning. A true confirmation check, according to Long and sato, confirms that the listener has heard and understood the interlocutor's message. These were classified as confirmation checks, however, because Long and sato (1983) state that confirmation checks may be exact or semantic, complete or partial repetition or the previous speaker's utterance. This may be a problem with coding. The coder must decide whether to code according to the underlying function of the question or form of the question. However, in this study teacher repetitions with rising intonations such as the ones in the above example (lines 7 and 9) were consistently coded as confirmation checks.

An example from the corpus of the way in which the category of confirmation checks was intended to function follows:

1 T: Any other ideas?

2 S: I think the education and the family very 3 important and after that everything is very 4 important.

5 T: Education is very important?

In line 5, the teacher is repeating a portion of the student's communication in order to sort out just what she 
means in lines 2 thru 4. The teacher has a genuine need here for more information in order to understand the student's meaning.

The fifth hypothesis states that clarification requests by the teacher will occur more frequently following referential questions than following display questions. It was reasoned that if students were supplying the teachers with new information in their answers to referential questions rather than supplying teachers with answers the teachers already knew (answers to display questions), more negotiating of meaning would be going on, and therefore clarification requests would increase.

An example from Teacher 2's class illustrates a clarification request:

1 T: You mean rich lots of money? Okay.

2 S: Or get some electric or some ( ).

3 T: Could you repeat that? I just wasn't $4 \quad$ listening.

5 S: Get some electric or some TV or something.

6 T: Oh.. A lot of consumer goods. We call those 7 consumer goods ... television, microwave ..

In line 3, the teacher is using a clarification request in order to get more information to clarify the student's utterance. The empty parentheses in line 2 represents an utterance the researcher could not reliably transcribe. The 
teacher had a difficult time understanding what the student was trying to say in line 2 and therefore asked the student to repeat what was just said. Most clarification requests found in the corpus asked for information from students when a breakdown in communication was taking place such as the teacher being unable to hear the students' response because of external noise.

The sample of clarification requests, however, was too small to perform a statistical test. Perhaps if learner proficiency were lower, a greater number of both clarification requests and confirmation checks would have been observed. Five of the six classes coded in this study were at the highest level of reading at a community college. Therefore, the students were likely to be proficient in speaking.

\section{IMPLICATIONS FOR TEACHING}

As predicted, ESL reading teachers in adult reading classes did ask a greater number of display questions (low cognitive levels) than referential questions (high cognitive levels) during teacher-student discussions. This is similar to first language classrooms, where teachers at the elementary level (see Guzzak, 1967; Willson, 1973) and the secondary level (see Davis \& Tinslig, 1967; Gallagher, 1965) tend to also ask questions at low cognitive levels. Also as 
hypothesized, learner responses to referential questions were longer in length, more syntactically complex, and contained more connectives than display questions.

Responding to referential questions then gives non-native speakers an opportunity to practice the "use" of the target language in Widdowson's sense (1978). Use of the language is revealed through performance which is demonstrated by the speakers' ability to use linguistic rules for effective communication. Widdowson (1978) further explains that it is possible for language learners to know the linguistic rules of a language through having learned sentence patterns without knowing how to use these rules in a communicative manner. Therefore, in answering referential questions, those questions which ask a student to provide new information, students are put in a situation where communicative language is used in the classroom.

Use of communicative language, or a genuine exchange of information, was recommended by white and Lightbown (1984). After studying four secondary ESL classes, they concluded that teacher's questions should not be questions with answers already known to teachers (low cognitive levels) but questions with answers that are unknown to teachers (high cognitive levels). In asking these high cognitive level questions students and teachers would be involved in conversation that is like everyday discourse. The existence 
of this gap in information would also slow teachers down in respect to the amount of time they would wait for student responses.

Use of low cognitive and high cognitive level questions has been studied extensively in the first language classroom. Two studies by Smith (1978) dealing with the length of learner responses parallel the findings reported here. In the first study, elementary school students' responses to interpretive level (higher cognitive level) questions contained longer communication units (c-unit) than factual (display) questions. (The c-unit is a linquistic unit that cannot be further divided without loss of meaning). In the second study elementary and secondary students' responses to broad (referential) questions were longer than their responses to narrow (display) questions. As described in the present study, the mean length in words to referential questions was longer than the mean length of words to display questions. If one of the goals of the second language classroom is to get students to produce more in the target language, this study indicates that asking referential questions can help achieve that goal.

Similarly, Cole and Williams (1973) in a descriptive study of elementary students and their teachers found a significant association between the cognitive level of the teachers' questions and the cognitive level of students' 
responses, and the length and syntax of those responses. The Cole and Williams study supports the claim in the present study that holds that higher level student responses will require students to use greater syntactic complexity.

A descriptive work by Dillon, however, supplies conflicting evidence with the findings in the present study concerning the mean length of student response. In one instance, Dillon classified questions as either open or closed. Open questions required at least several phrases or a sentence in the response, whereas closed questions were structured so that a single word or phrase would be needed in the response. (Open questions could be considered analogous to referential questions and closed questions could be considered analogous to display questions.) Contrary to the findings in the present study, the mean length of response to closed questions was significantly longer than the mean length of student response to open questions. In a discussion of this unexpected finding, Brock (1985) attributed this result to the way in which Dillon defined student turns. Perhaps if Dillon had recognized the change of speakers within student responses, the results might have been different.

The results of the present study suggest that learner responses to referential questions are longer in length, more syntactically complex and contain more connectives than 
display questions. This is an important consideration in the second language classroom where one of the goals of the language teacher is to stimulate the learner's use of the target language. The classroom is often the only arena where learners have an opportunity to utilize new language forms in the target language. Therefore, a recommendation from this study would be that teachers increase the number of referential questions in their classrooms to stimulate student output.

There is evidence in other studies that teachers can, with training, increase the frequency of higher cognitive level questions, or referential questions, in the classroom (Gall, 1970; Rogers \& Davis, 1970; Galassi, Gall, Dunning \& Banks, 1974; Chewprecha, Gardner, \& Sapianchai, 1980). A variety of training methods has been used including videotape, written pamphlets and instructions, and audiotape. Some studies, however, suggest that all training methods are not equally effective. For instance Galassi and his co-workers (1974) found that written transcripts of classroom dialogues were a more effective training tool than videotapes of the same dialogues. Yet in Brock's study (1986) of the effects of referential and display questions on ESL classroom discourse, teachers were able to increase the number of referential questions asked in an ESL reading classroom after only a twenty-minute training session. The 
training session pointed out the distinction between referential and display questions by supplying examples of each type of questions and having the teachers practice the formation of referential questions.

In conclusion, recommendations based on the data gathered from the present study include training teachers to be aware of the use of referential and display questions in classroom discussions. This is a cost-free and easy way to implement changes in teaching techniques. If teachers could increase the number of referential questions asked, students' overall output in the target language could be increased. As important as increasing the number of referential questions is the recommendation that teachers allow students time to answer these questions. In everyday discourse, as opposed to classroom discourse, when a question is asked there is a genuine need for information and the questioner will pause to listen for an answer. In using referential questions, teachers would be required to actually listen to students' answers just as they would listen to another native speaker.

\section{LIMITATIONS}

Some of the limitations in this study stemmed from the freedom allowed the teachers in teaching the lesson. Although the same reading selection was used in all six 
classes, teachers' approaches to the selection varied. The researcher transcribed the first twenty minutes of teacher-student interaction concerning the reading selection. In two classes this involved pre-reading exercises where the teachers asked open questions (classified as referential questions) to which almost every student response was accepted. In another class, a teacher-designed worksheet was discussed in student groups. The worksheet included exercises that defined the main ideas of each paragraph, five questions calling for factual information from the reading (display questions), and two questions calling for opinion (referential questions). After the students worked in small groups, the teacher led a discussion based on a review of the worksheet. The discussion on the last two questions from the worksheet calling for opinions was not included in the transcription because the twenty minutes specified for the present research had already been transcribed.

In order to get a more fair sample of student-teacher interactions in all classes, teachers could be instructed to ask questions at a specific time during the lesson. Expanding on the research in the present study, teachers could be made aware of the purpose of the study in order to discover different effects certain questions have on classroom discussion, and be trained to increase the number 
of referential questions asked in a discussion during a reading class. Teachers could also be trained to extend their wait-time (the time between the end of a teacher's utterance of a question and the beginning of the student's response).

The fact that wait-time was not calculated is another limitation of the present study. At the extreme was Teacher 5 who did not stop asking questions long enough to allow students to answer. In Teacher $5^{\prime} \mathrm{s}$ class although the number of referential questions was almost double the number of display questions asked, students responded to only $36 \%$ of the referential questions asked. Student responses to Teacher 5's referential questions were shorter, less syntactically complex, and contained fewer connectives than other student responses to other teachers' referential questions. It is, therefore, not enough to say that an increase of referential questions will be enough to stimulate student output. Wait-time is seen as an important factor.

Research reported by Tobin (1987) states that wait-time is an important instructional variable when high cognitive level learning is the objective. It may be the case that some teachers wait longer after asking referential questions indicating that wait-time is a factor in the longer more complex responses observed. However, it may be the case 
that referential questions elicit longer more complex answers than display questions regardless of the wait-time involved. The question of whether the same wait-time for both referential and display questions would produce different types of features in student responses is unanswered in this study.

Finally, some of the limitations of the present study involved the use of Long and Sato's seven-category taxonomy of question functions. One of the problems in using this taxonomy to code questions was the difficulty in separating the function of questions from their forms. Though the transcripts were all coded consistently according to the researcher's understanding of Long and Sato's taxonomy, there were some questions that were problematic when coding. One of the problems is illustrated by the following example from the corpus:

1 s: I think that the lady, the lady who are working and ... the man doesn't work more than the woman.

4 T: Are you talking about here in America?

5 S: Yeah.

6 T: You're saying that the ladies go out, the women go out, and work. When you say too much you mean they work too hard?

9 S: Yeah. 
10 T: More than they should?

11 S: Uh huh.

12 T: And you think maybe that's why some women

13 are the head of the family?

14 S: Yeah.

15 T: You think that's the case in some families?

$16 \mathrm{~S}$ : In Mexico, when they get divorced, the 17 couple...the daughter is the head of the 18 family because she works. She bring money 19 to the household.

The teacher's five questions above were all coded as confirmation checks. According to Long and Sato's taxonomy, confirmation checks are either Yes/No or uninverted questions with rising intonation that presuppose a "Yes" answer. They may involve complete or partial repetition of the previous speaker's utterance in order to understand or dispel belief. The question in line 4 is a Yes/No question but it doesn't truly check on what the teacher heard. The teacher interrupted the student to compel the student to supply more information. The questions in lines 7 and 8 , and 10 refer back to the student's original utterance in line 1 thru 3. Again, according to Long and Sato's taxonomy, the two questions in lines 7 and 8 , and 10 are confirmation checks but they seem to be leading the student to expand on his answers not because the utterance was 
misunderstood but because the teacher wanted the student to speak more. The question in line 12 seems to be a summing up of the teacher's previous questions rather than a genuine check of what the teacher had heard. The last confirmation check in line 15 seems to truly be requesting the student's opinion.

The above is an example of one problem found in using a taxonomy in which form is separated from function. Categorizing questions is not easy because of the many ways in which questions are used and the different forms questions can take. Further research on the subject of forms and functions of questions is needed.

Yet another limitation in using Long and Sato's taxonomy was the problem of fitting speech into categories without considering factors other than the actual speech. Although the coding of the questions in the following example from the corpus was based on what was actually recorded and transcribed, factors such as the teacher's background knowledge could have had an effect on the coding. The following is an example from Teacher 4's class:

1 T: ... Phung, tell us about your country. Do 2 you think that nuclear family or extended 3 families are common in your country? In $4 \quad$ Vietnam, how is it?

5 s: In Vietnam $\ldots$ uh $\ldots$ father $\ldots$ uh $\ldots$ 
6

10 S: Yeah. Yeah.

11 T: You're also from Vietnam, Henry.

12 S: Yeah.

13 T: Did you grow up in an extended family or a 14 nuclear family?

15 S: Nuclear family.

16 T: Nuclear family. Who was in your family?

17 S: My father, grandma, and my aunt, and ( ) 18 uncle and ...

19 T: Do you hear what Henry's saying?

20 S: Extended family.

21 S: Extended family.

22 T: Extended family. He grew up in an extended family. A nuclear family is small.

The teacher's first questions in lines 1 thru 3 were coded as referential questions which provided new information to the questioner. But if the coder had taken into account the fact that the ESL teacher in this class has over ten years of experience dealing with students from other cultures, the question could have been coded as a display question. In other words, the teacher already had a 
good idea of what the student's answer would be, based on her past knowledge of the Vietnamese culture. The next exchange with another student beginning on line 11 was a similar situation. In line 16 the teacher repeated the student's answer and proceeded to ask for more details with a referential question. However, the remaining lines of the exchange suggest that the teacher was not asking this question to truly acquire new information but to "test" the student's knowledge of the difference between nuclear and extended families. Therefore, within the context of the classroom, a question that appears to be asking for new information (referential question) could actually be testing a student's knowledge (display question).

The problem illustrated above presented itself to the researcher more than once in the coding of the transcripts. Throughout the study however, the researcher tried not to guess the teachers" "true" intent but coded the questions as they appeared within the context of teacher-student discussions. The researcher concluded that this problem exists in Long and Sato's taxonomy, and may also exist in other taxonomies where language is categorized.

The final limitation of using Long and Sato's taxonomy involved the counting of questions. Each question was counted separately even if.its meaning was similar to a previous question but uttered in a different manner. An 
example from the corpus will clarify this point:

$\begin{array}{ll}1 & T: \text { I'd like to know from some of you, in your } \\ 2 & \text { home, when you were growing up who was } \\ 3 & \text { living in the house? In other words } \\ 4 & \text { ((student enters the classroom)) Hi ... come } \\ 5 & \text { in..Uhm... so in your family, how many of } \\ 6 & \text { you had your mother, father, and yourself } \\ 7 & \text { and your brothers and sisters all living in } \\ 8 & \text { the same house? }\end{array}$

The two questions in the above example were classified as referential questions. They ask for information that is not known by the questioner. The question in lines 5 thru 8 is an elaboration of the initial question found in lines 1 thru 3. The second question is pushing students to supply information on the same topic. The seven-category taxonomy by Long and sato used in this study did not have categories for elaborations or repetitions. Therefore, in the present study each question was counted separately. If there were categories for these types of questions, the number of referential questions in this study would probably have been reduced. Though no statistical analysis was done on this point, it appears to the researcher that these elaborations and repetitions were more frequently used with referential questions. More research is needed on this point. 
CONCLUSIONS

This descriptive study has examined the functions of teacher questions and their effects on student responses in the ESL reading classroom. Observing these patterns of teacher-student interactions can aid in the understanding of non-native speakers' efforts to internalize classroom input.

As reported in this study, teacher use of referential questions increased the length, syntactic complexity, and the use of connectives in student responses. In general, output was increased. A current theory by swain supports the idea that output is an important factor in second language acquisition. Swain (1983) holds that it is possible to comprehend input without a syntactical analysis of that input. But "producing the target language may be the trigger that forces the learner to pay attention to the means of expression needed in order to sucessfully convey his or her own intended message" (p. 249).

Since referential questions supply students with the opportunity to communicate in a way that resembles everyday discourse, their use, particularly in the ESL classroom, is highly recommended. 


\section{REFERENCES}

Arnold, D.S., Atwood, R.K., \& Rogers, V.M. (1974). Questions and response levels and lapse time intervals. Journal of Experimental Education, 43, 11-15.

Brock, C. A. (1985). The effects of Referential Questions on ESL Classroom Discourse. Occasional Paper Series No. 1, Department of English as a second Language, University of Hawaii at Manoa.

Brock, C.A. (1986). The Effects of Referential Questions on ESL Classroom Discourse. TESOL Quarterly, 20, 47-59.

Celce-Murcia, M., \& Larsen-Freeman, D. (1983). The Grammar Book: An ESL/EFL teachers' course. Rowley, MA: Newbury House.

Chewprecha, T., Gardner, M. Sapianchai, N., (1980). Comparison of training methods in modifying questioning and wait time behaviors of Thai high school chemistry teachers. Journal of Research in Science Teaching, 17, $191-200$.

Cole, R. A., \& Williams, D. M. (1973). Pupil responses to teacher questions: Cognitive level, length and syntax. Educational Leadership, 31, 442-445.

van Dijk, T. (1977). Semantic macro-structures and knowledge frames in discourse comprehension. In $M$. Just \& P. Carpenter (Eds.) Cognitive Processes in Comprehension, (pp. 3-32). Hillsdale, NJ: Lawrence Erlbaum Associates.

Davis, O.L., \& Tinsley, D. C. (1967). Cognitive objectives revealed by classroom questions asked by social studies teachers. Peabody Journal of Education, 45, 21-26.

Dillon, J.T. (1981). Duration of response to teacher questions and statements. Contemporary Educational Psychology, 6, 1-11. 
Dillon, J.T. (1982). Cognitive correspondence between question/statement and response. American Educational Research Journal, 42, 540-551.

Dillon, J.T. (1984). Research on questioning practice. Educational Leadership, $42,50-56$.

Freed, B.F. (1978). Foreigner talk: A study of speech adjustments made by native speakers of English in conversation with non-native speakers. Unpublished doctoral dissertation, University of Pennsylvania.

Galassi, J.P., Gall, M.D., Dunning, B. \& Banks, H. (1974). The use of written versus videotape instruction to train teachers in questioning skills. Journal of Experimental Education, $43,16-23$.

Gall, M. D. (1970). The use of questions in teaching. Review of Educational Research, 40, 707-721.

Gallagher, J.- J., Aschner, M. J. (1963). A preliminary report on analyses of classroom interaction. Merrill-Palmer Quarterly of Behavior and Development, $9(3), 183-194$.

Gallagher, J. J. (1965). Expressive thought by gifted children in the classroom. Elementary English, 42, $559-568$.

Guilford, J.P. (1956). The structure of intellect. Psychological Bulletin, 53 (4), 267-293.

Guszak, F.J. (1967). Teacher questioning and reading. The Reading Teacher, 21, 227-234.

Kearsley, G. P. (1976). Questions and question-asking in verbal discourse: A cross - disciplinary review. Journal of Psycholinguistic Research, 5, 355-375.

Keenan, E.O., Schieffelin, B.B. \& Platt, M. (1978) Questions of Immediate Concern. In N. Goody (Ed.) Questions and Politeness, (pp. 44-55). London: Cambridge University Press.

Kirn, E. \& Hartman, P. (1985). Interactions 1: A reading skills book, New York: Random House.

Lamb, W.G. (1976). Ask a higher-level question, get a higher level answer. Science Teacher, 43, 22-23. 
Loban, W. (1963). The Language of elementary school children (Research Rep. No. 1). Champaign, IL: National Council of Teachers of English.

Long, M.H. (1980). Inside the "black box": Methodological issues in classroom research on language learning. Language Learning, 30, 1, 1-42.

Long, M.H. (1981). Questions in foreigner talk discourse. Language Learning, 31, 1-42.

Long, M.H., \& Sato, C.J. (1983). Classroom foreigner talk discourse: Forms and functions of teachers' questions. In H.W. Seliger and M.H. Long (eds.), Classroom oriented research in second language acquisition. Rowley, MA: Newberry House., 268-285.

Mehan, H. (1979). "What time is it Denise?": Asking known information questions in classroom discourse. Theory into Practice, 18, 285-295.

Mills, S.R., Rice, C.T., Berlinger, D.C., \& Rousseau, E.W. (1980). The correspondence between teachers' questions and students' answers in classroom discourse. Journal of Experimental Education, 48, 194-204.

Rogers, V., \& Davis, O.L. (1970, March). Varying the cognitive levels of classroom questions: An analysis of student teachers questions and pupil achievement in elementary school social studies. Paper presented at the annual meeting of American Educational Research Association, Minneapolis.

Seliger, H. \& Long, M. (1983). Classroom oriented research second language acquisition. Rowley, MA: Newbury House.

Smith, C.T. (1978). Evaluating answers to comprehension questions. The Reading Teacher, 31, 896-900

Swain, M. (1985). Communicative competence: some roles of comprehensible input and its development. In $\mathrm{S}$. Gass \& C. Madden (Eds.). Input in Second Language Acquisition. Cambridge, MA: Newberry House Publishers.

Tobin, K.G. (1980). The role of wait-time in higher cognitive level learning. Journal of Research in Science Teaching, 17 (5), 469-475. 
Tomiyana, M. (1980). Grammatical errors and communication breakdown. TESOL Quarterly, 14, 71-79.

White, J. \& Lightbown, P. (1984). Asking and answering in ESL classes. Canadian Modern Language Review, 40, $228-244$.

Widdowson, H.G. (1978). Teaching language as communication. oxford: Oxford University Press.

Willson, L.A. (1973). Changes in mean levels of thinking in grades 1-8 through use of an interactive system based on Bloom's taxonomy. Journal of Educational Research, 66, 13-50. 
APPENDIX A

READING SELECTION AND VOCABULARY LIST 
WOMEN IN THE NUCLEAR FAMILY

from Interactions 1: A Reading Skills Book

The family is changing. In the past, grandparents, parents, and children used to live together; in other words, they had an "extended family". Sometimes two or more brothers with their wives and children were part of this large family group. But family structure is changing throughout the world. The "nuclear family" consists of only one father, one mother, and children; it is becoming the main family structure everywhere.

The nuclear family offers married women some advantages: they have freedom from their relatives, and the husband does not have all the power of the family. Family structure in most parts of the world is still "patriarchal"; that is, the father is the head of the family and makes most of the important decisions. Studies show, however, that in nuclear families, men and women usually make an equal number of decisions about family life. Also, well educated husbands and wives often prefer to share the power.

But wives usually lived in extended families, sisters, grandmothers, and aunts helped one another with housework and childcare. In addition, older women in a large family 
group had important positions. Wives in nuclear families do not often enjoy this benefit, and they have another disadvantage, too: women generally live longer than their husbands, so older women from nuclear families often have to live alone.

studies show that women are generally less satisfied with marriage than men are. Housework and childcare were a full-time job, and there was no time for anything else. Of course, this situation is changing. Women now work outside the home and have more freedom than they did in the past. Why, then, are some women still discontent?

In most parts of the world today, women work because the family needs more money. However, their outside jobs often give them less freedom, not more, because they still have to do most of the housework. The women actually have two full-time jobs--one outside the home and another inside--and not much free time.

The nuclear family will probably continue to be the main family from of the future. Change, however, usually brings disadvantages along with benefits, and the family forms of the past had many advantages. 


\section{VOCABULARY}

group

freedom

housework

disadvantage

structure

relative

childcare

marriage

advantage

power

change share

main

married

well-educated

satisfied

generally

actually

nuclear family

head of the family

make decisions

full-time job 
APPENDIX B

TRANSCRIPTION SAMPLE 
TRANSCRIPTION SAMPLE

KEY TO TRANSCRIPT

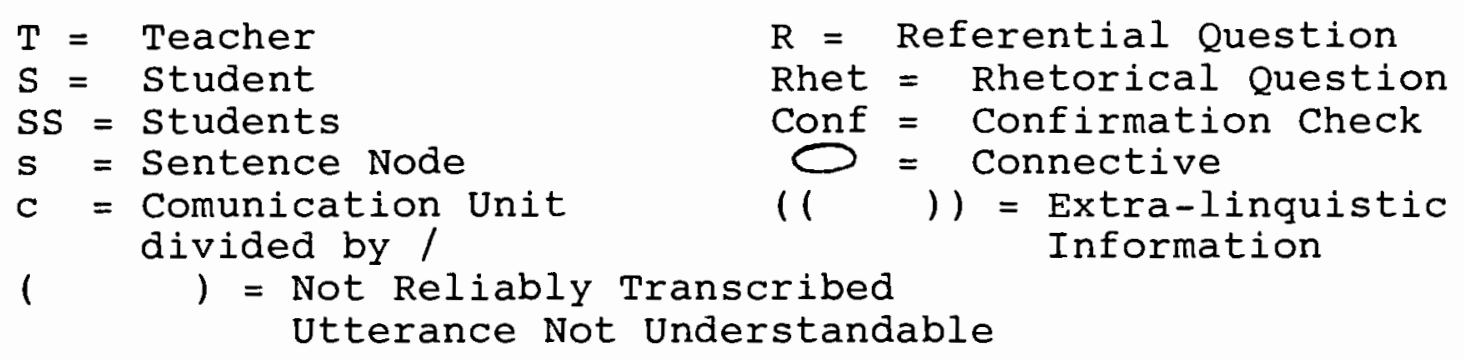

T: Right now I'd like to talk for a minute about families. We're going to read something about families and let's just think for a minute what that word means. ((Teacher writes

$R$ on the board.) What does family mean to you? What's

$R$ the first thing you thin of when you think of family?

SS: Father, mother, children, wife ((laughter))C

R T: Now what's funny about that?

s: $I$ don't know ((more laughter)). $\mathrm{C}$

T: O.K. What else do you think of when you think of

$R R$ family? Does it give you a good feeling or a bad feeling?

$R R$ Does it make you angry? Does it make you feel happy?

s: Good feeling./ Everyone is thinking of family../ Everyone laúgh here probably. $3 \mathrm{C}$

Rhet $T$ : well, that's true. It made people laugh, didn't it? 
$R$ ((Teacher writes on board. laughter)) What else?

s: Comfortable $C$

T: Comfortable. Great. ((Continues on board.)) Can

$R$ you think of anything families do?

s: Lot of love ... how do you say .. loving? C

T: Loving.

S: Happy .

T: Happy. Are families just father, mother, wife and

D children?

Ss: No.. Husband, grandfather, $C$

$\mathrm{T}$ : Grandfather.

S: Brother.

T: Brother.

$\mathrm{T}$ : Sisters.

T: Sister.

S: Uncles.

$\mathrm{T}$ : Uncles.

S: Aunts.

$\mathrm{T}$ : Aunts.

SS: Cousins, niece, nephews, grandchildren.

$R$ T: Grandchildren. How many people in here have

grandchildren?

SS: Uh .. ( )

RR S: You have grandchildren? You don't?

S: No. 
T: How do you think the idea of family in the United $R$ states is different than the idea of family in your country?

$R$ Does that make you think of anything?

S: I think it's different because American family is not very $(, C$

Conf. T: Not very?

s: Close.

T: Close.

S: Separated.

Conf. T: So for you family means closeness?

S: Yes.

$\mathrm{T}$ : But it can also mean separateness in this country

$R$ you think. Anything else?

S: Yeah. In the United states family means all relatives.. includes... around... all relatives..C

T: You mean like uncles, cousins, niece

S: Aunts, uncles, cousins.. 